\title{
PHYTOREMEDIATION AS A TOOL FOR THE REMEDIATION OF WASTEWATER RESULTING FROM DYEING ACTIVITIES
}

\author{
UgYa, A. Y. ${ }^{1,2}-$ HUA, X. ${ }^{1}-$ MA, J..$^{*}$ \\ ${ }^{1}$ College of New Energy and Environment, Jilin University, Changchun 130012, China \\ ${ }^{2}$ Department of Environmental Management, Kaduna State University, Kaduna, Nigeria \\ *Corresponding author \\ e-mail: jincaima@jlu.edu.cn (Dr/Professor Jincai Ma)
}

(Received 24 $4^{\text {th }}$ Dec 2018; accepted $14^{\text {th }}$ Feb 2019)

\begin{abstract}
The production of dye is usually associated with several intermediate products and waste which are usually toxic and bio-hazardous and often disturb the environmental equilibrium. The present study is aimed at selecting macrophytes with the highest efficiency in the remediation of wastewater generated from dyeing activities. The test macrophytes were introduce into three different troughs for each plant containing $100 \%$ wastewater, $50 \%$ wastewater and control (100\% borehole water). After 21 days the macrophytes were removed for further analysis. The reduction efficiency, Heavy metal bioconcentration and bio translocation factor of the macrophytes was determined. The result obtained shows that the test macrophytes improved the $\mathrm{pH}$ but were not able to improve the color of the wastewater. Lemna minor have the highest reduction efficiency for BOD, COD, Oil, and Grease while Pistia stratiotes have the highest reduction efficiency for TDS and TSS, Eicchornia crassipes have the highest reduction efficiency for $\mathrm{Cl}^{-}$and Salvinia molesta have the highest reduction efficiency for phenol and ammonical Nitrogen. All macrophytes recorded high reduction efficiency for heavy metal removal but Pistia stratiotes and Eicchornia crassipes had the highest bioconcentration and translocation. These macrophytes should be introduced to the local dye users as a costless and environmentally friendly way of treating wastewater resulting from dyeing activity.
\end{abstract}

Keywords: Azolla pinnata, Lemna minor L., Eicchornia crassipes, Pistia stratiotes, Salvinia molesta

\section{Introduction}

The world ever increasing population and adoption of industrial based lifestyle have led to an increasing in anthropogenic activities which has lots of effects on the biotic community. The availability of water, both in quality and quantity, is one of the prime factors in deciding the growth of towns and cities as well as industries (Amare et al., 2018a; Costa et al., 2018; Fernandes et al., 2018). It is thereby in the best interest of the world if water is properly treated for the purpose of reuse. In Northern Nigeria, different communities and ethnic groups use numerous plants as dyeing agents. This has greatly influenced cultural acceptability and easy method of survival. The synthesis of organic dye was introduced in 1871 and was practiced in Egypt, Persia, China and India thousands of years ago using natural materials derived from insects, plants, shellfish etc. as dyestuff. Dyes are generally fast as they retain their color in the fiber throughout the textile making process and under exposure to normal wear including sunlight, water, and detergent washing. Dye is a soluble compound that can either be absorbed or retained by the fiber. The production of dye is usually associated with several intermediate products and waste which are usually toxic and bio-hazardous and often disturb the environmental equilibrium. Local dye users of Faskari road (Fig. 1) who use dye in the dyeing of cloths and other garments create a large quantity of wastewater which contains different pollutants. The wastewater generated during dying activities is 
characterized by high BOD, COD, Acidity, Deep color of Different Shades, levels of chlorides etc (Haddad et al., 2018; Lyu et al., 2018; Pandian et al., 2018). These pollutants are produced in an effort to improve the looks of the inhabitants of Kaduna south local government but ironically the lack of treatment facilities reverse the same standard by impacting negatively on the environment (Amare et al., 2018b; Carvalho et al., 2018).

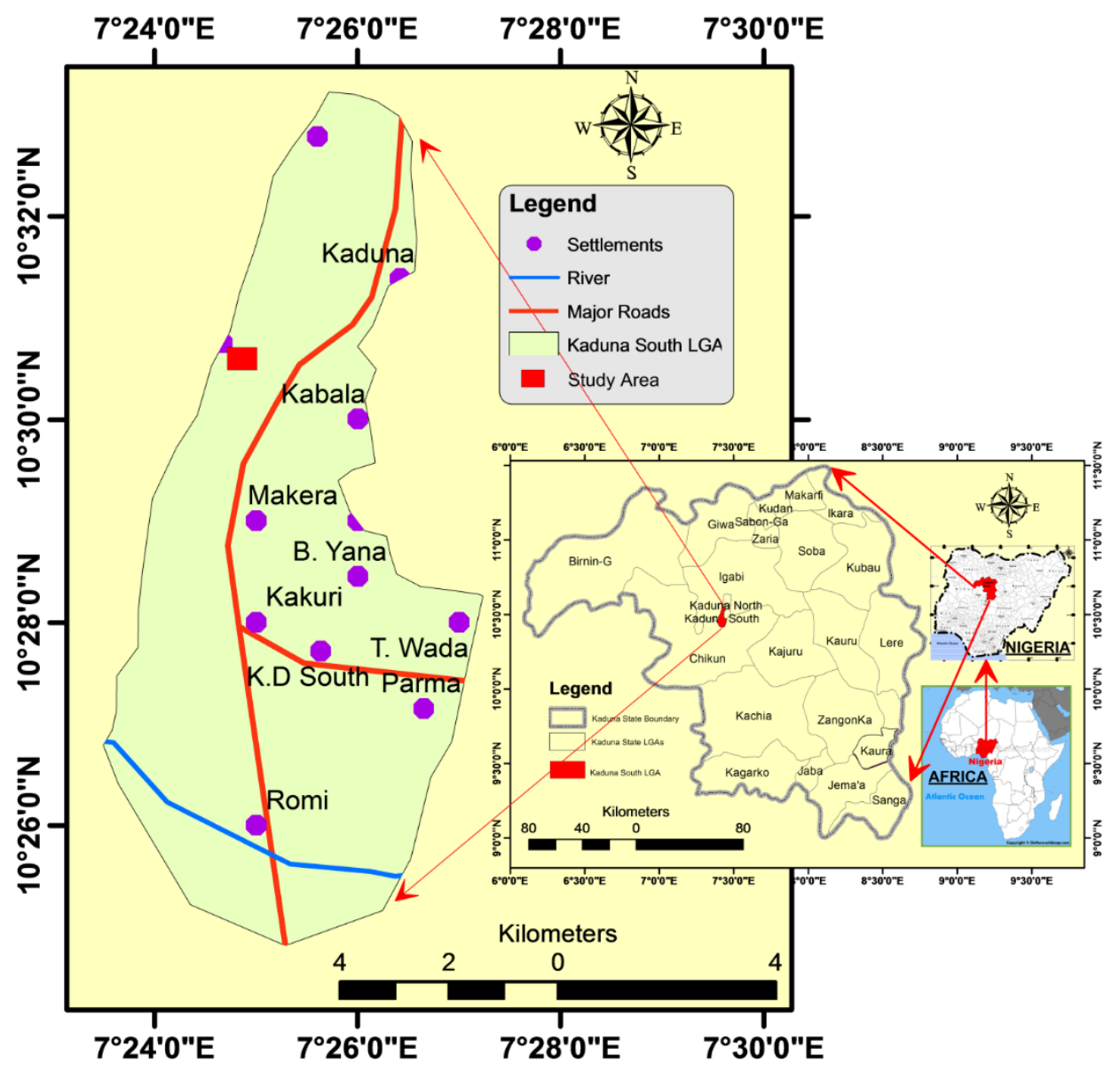

Figure 1. Map showing Study Area

The wastewater is released into drainage system without treatment, eventually, this toxic wastewater makes it way into River Kaduna which is the nearby water body (Bununu et al., 2015; Ogwueleka, 2014, 2015). Some of the wastewater can seep into aquifers and pollute underground water since they cannot be confined within specific boundaries (Braun et al., 2018; Demarco et al., 2018; Fernandez San Juan et al., 2018). The untreated wastewater tends to have an ecological impact on the nearby water bodies which is river Kaduna leading to increased nutrient load leading to eutrophication, which is open water can progressively lead to oxygen deficiency, algae blooms, and death of aquatic life. Several technologies are available to remediate this wastewater before discharge. However, many of these technologies are costly, so not easily accessible (Jiang et al., 2018; Osti et al., 2018; Zhao et al., 2018). Phytoremediation can provide a long lasting, cost effective, long lasting and aesthetic solution to the remediation of this wastewater, since macrophytes such as Lemna minor L., Azolla 
pinnata, Pistia stratiotes, Eicchornia crassipes and Salvinia molesta which are easily accessible have been proof to have phytoremediation potentials by researchers such as (Saraswat and Rai, 2018; Ting et al., 2018; Vanhoudt et al., 2018) etc. The present study is aimed at selecting macrophytes with the highest efficiency in the remediation of wastewater generated from dyeing activities.

\section{Materials and Methods}

\section{Plant Sampling and Identification}

Young macrophytes of Lemna minor L., Azolla pinnata, Pistia stratiotes, Eicchornia crassipes, and Salvinia molesta were collected from different pond located at Kaduna, Kaduna State, Nigeria and identity using relevant guide. The young plants were selected for these studies due to their ability to double their size in 3 weeks. The plants were authenticated at the herbarium of the department of botany (Table 1), Ahmadu Bello University Zaria, Kaduna State, Nigeria.

Table 1. Test Macrophytes Used for Phytoremediation

\begin{tabular}{c|c|c|c}
\hline SN & PlANTS & COMMON NAME & ACCESSION NUMBER \\
\hline $\mathbf{1}$ & LEMNA MINOR L. & DUCKWEED & L.6935 \\
$\mathbf{2}$ & EICHHORNIA CRASSIPES & WATERHYACINTH & 3268 \\
$\mathbf{3}$ & PISTIA STRATIOTES & WATERLETTUCE & 1977 \\
$\mathbf{4}$ & AZOLLA PINNATA & WATERVELVET & 0678 \\
$\mathbf{5}$ & SALVINIA MOLESTA & KARIBA WEED & 01689 \\
\hline
\end{tabular}

\section{Water Sampling}

Wastewater was collected from dyeing point of Faskari road located in TudunWada of Kaduna South Local Government, Kaduna State, Nigeria from March 2017-March, 2018 (Fig. 1). The collection, storage, transportation and analysis of the sample for the parameters such as $\mathrm{BOD}_{5}, \mathrm{COD}, \mathrm{pH}$, electrical conductivity, Chlorides, Ammonical Nitrogen, phenol, phosphate, total suspended solids, total dissolved solids, oil and grease before treatment was done according to (AFNOR, 2001).

\section{Phytoremediation Setup}

To access the phytoremediation efficiency of these macrophytes in the improvement of dyeing wastewater, an offsite culture experiment was performed in the general biology laboratory of Kaduna State University. The test plants were thoroughly washed using borehole water and distilled water then kept on a filter paper to remove excess water before transferring into fifteen different troughs having a capacity of five liters. The experiments were grouped into 5 groups with each group consisting of three troughs as shown below:

Group 1: Lemna minor L. was inoculated in wastewater of different concentration below:

$>100 \%$ of wastewater.

$>50 \%$ of wastewater.

$>0 \%$ wastewater (control). 
Group 2: Eicchornia crassipes was inoculated in wastewater of different concentration below:

$>100 \%$ of wastewater.

$>50 \%$ of wastewater.

$0 \%$ wastewater (control).

Group 3: Pistia stratiotes was inoculated in wastewater of different concentration below:

$>100 \%$ of wastewater.

$>50 \%$ of wastewater.

$>0 \%$ wastewater (control).

Group 4: Azolla pinnata was inoculated in wastewater of different concentration below:

$>100 \%$ of wastewater.

$>50 \%$ of wastewater.

$0 \%$ wastewater (control).

Group 5: Salvinia molesta was inoculated in wastewater of different concentration below:

$>100 \%$ of wastewater.

$>50 \%$ of wastewater.

$>0 \%$ wastewater (control) (Qin et al., 2016, Qu et al., 2017)

After 21 days the plants were removed from the treated water, the treated water was thus filtered before the re-determination of $\mathrm{BOD}_{5}, \mathrm{COD}, \mathrm{pH}$, electrical conductivity, Chlorides, Ammonical Nitrogen, phenol, phosphate, total suspended solids, total dissolved solids, oil and grease by using standard method as described by (AFNOR, 2001), the color change before and after treatment of the wastewater was also observed. The removal efficiency of each of the macrophyte was thus calculated according to the method employed by Ugya (2015) as represented below:

$$
x=\frac{B-A}{B} X \frac{100}{1}
$$

where:

$\mathrm{B}=$ Final Concentration.

$\mathrm{A}=$ Initial concentration.

$\mathrm{X}=$ ReductionEfficiency.

The experiment was repeated for nine months to enable the determination of the mean removal efficiency of each of the macrophyte (Akhtar et al., 2016; Bokhari et al., 2016; Zhao et al., 2016).

\section{Heavy Metal Bioconcentration and BiotranslocationFactor}

After remediation macrophytes were removed and separated into leaves, stems, and roots. These parts were washed using tap water, ionized water then oven dried at $70^{\circ} \mathrm{C}$ before grounding. The grounded plant materials were then subjected to acid digestion using $\mathrm{HNO}_{3}$ and $\mathrm{HClO}_{4}$. After digestion, the sample was then analyzed using Atomic Absorption Spectrophotometer for the concentration of heavy metals $\left(\mathrm{Ni}^{2+}, \mathrm{Cr}^{3+}, \mathrm{Cd}^{2+}\right.$, and $\mathrm{Pb}^{2+}$ ) present in theroot and shoot (leave and stem) of the macrophyte. These were then used in the determination of Bioconcentration and biotranslocation factor using Equations (2) and (3) below: 
Bioconcentration Factor $=\frac{\mathrm{a}}{\mathrm{b}}$

Biotranslocation Factor $=\frac{\mathrm{c}}{\mathrm{d}}$

where:

$\mathrm{a}=$ metal concentration in root.

$\mathrm{b}=$ metal concentration in wastewater.

$\mathrm{c}=$ metal concentration in shoot.

$\mathrm{d}=$ metal concentration in root.

The concentration of heavy metals present in the wastewater was also determined before and after the treatment process for the determination of heavy metal reduction efficiency using Equation (1).

\section{Data Analysis}

With the objective of determining the macrophyte with the highest reduction efficiency, biotranslocation factor and bioaccumulation factor, Data were analysed using IBM SPSS statistics version 23 for two-way analysis of variance (ANOVA).

\section{Result and Discussion}

\section{Wastewater Colour and pH Reduction Efficiency}

The result obtained shows that all the test plants were not able to improve the color of the wastewater from dark brown although Lemna minor L and Pistia stratiotes were able to change the color of the wastewater to pale yellow after treatment. The $\mathrm{pH}$ of the wastewater was improved by all the test plants as the $\mathrm{pH}$ was not reduced but increase. On the mean scale, the macrophytes were able to increase the $\mathrm{pH}$ of the water from 4.2 to 7.3 (i.e from acidic to neutral $\mathrm{pH}$ ). The $\mathrm{pH}$ of the dyeing wastewater was increased from high acidity to neutral by all the aquatic macrophytes, this increase in $\mathrm{pH}$ could be attributed to the utilization of $\mathrm{CO}_{2}$ by the test plants for photosynthesis (Irawati et al., 2017; Singh and Rai, 2016; Victor et al., 2016). Some recent studies of the success of increase in $\mathrm{pH}$ resulting from the use of macrophytes include workdone by researchers such as Galal et al. (2017), Klink (2017), Maleva et al. (2016), Zhao et al. (2017) with references to different wastewater. The color removal efficiency of Pistia stratiotes could be attributed to the property of proper particle sedimentation by Pistia stratiotes or the ability of the root of Pistia stratiotes to retain both coarse and fine particle (Kaminski et al., 2014; Neagu et al., 2014).

\section{The efficiency of Macrophytes in BOD, COD and EC Reduction}

The BOD and COD reduction by the macrophytes is in the trend of Lemna minor, Pistia stratiotes, Eicchornia crassipes, Salvinia molesta, and Azolla pinata according to decreasing efficiency. Lemna minor was able to reduce BOD and COD from $645 \mathrm{mg} / \mathrm{l}$ to $75 \mathrm{mg} / \mathrm{l}$ and $1604 \mathrm{mg} / \mathrm{l}$ to $352 \mathrm{mg} / \mathrm{l}$, respectively (Fig. 2a). The pattern for EC reduction is different that of COD and BOD because Pistia stratiotes show a maximum EC reduction compare to other macrophytes (Fig. 2a). Similar pattern of COD, BOD and EC reduction by the macrophyte recorded in $100 \%$ wastewater was followed by the macrophytes in $50 \%$ wastewater and control (0\% wastewater) (Figs. 2b, 2c) signifying 
that Lemna minor has the highest reduction efficiency for COD and BOD while Pistia stratiotes is a has the hieghest reduction efficiency for EC. The high BOD and COD removal by macrophytes could be linked to the increase in $\mathrm{pH}$. $\mathrm{Ng}$ and Chan (2017) and Qin et al. (2016) reported an increase in $\mathrm{pH}$ by macrophyte and concluded that the macrophytes can be used to increase low $\mathrm{pH}$. This $\mathrm{pH}$ increase canalso be linked to COD and BOD reduction since studies by Qu et al. (2017) and Riaz et al. (2017) has shown that the presence of plants in water contributes to the growth of microbes which in turn causes the degradation of organic compounds. The reduction of EC is attributed to the growth of the macrophytes. Higher EC, COD and BOD removal has been reported by Augustynowicz et al. (2014), Di Luca et al. (2014), Török et al. (2015) using different macrophytes to remediate various wastewaters. The reduction of EC is attributed to the growth of the macrophytes (Haddad et al., 2018).

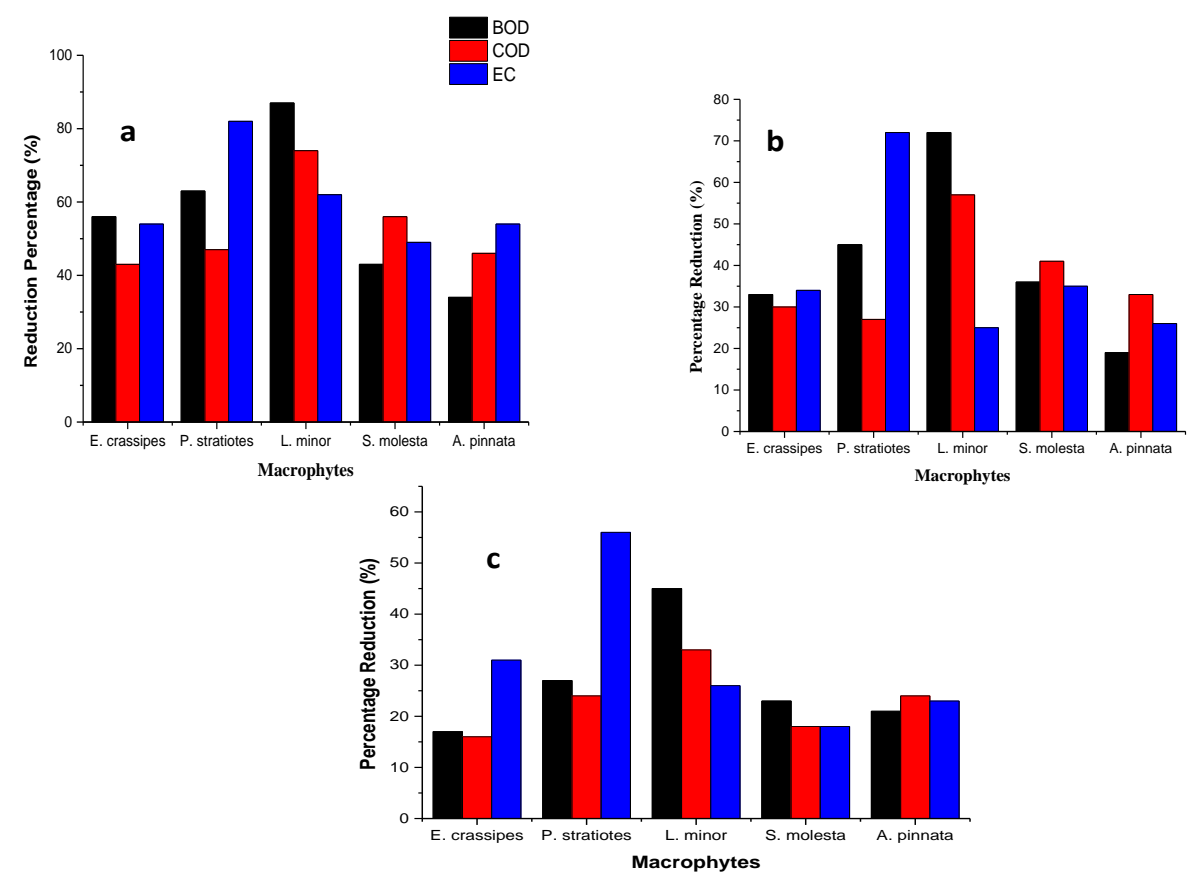

Figure 2. Efficiency of Macrophytes in BOD, COD and EC Reduction from (a) $100 \%$ Wastewater (b) 50\% Wastewater (c) Control

\section{The efficiency of Macrophytes in Oil and grease, Total Dissolved Solids and Total Suspended Solid Reduction}

The pattern of TDS and TSS removal was heighest in the control than $100 \%$ wastewater and 50\% wastewater, it was also noticed that the performances of all the plants were without any significant differences (Fig. 3c). Pistia stratiotes and Eicchornia crassipes have no significant differences in term of their reduction efficiency of TDS and TSS but both have a high significant difference to the removal efficiency of Lemna minor, Salvinia molesta and Azolla pinnata for TDS and TSS removal from both $75 \%$ wastewater and $100 \%$ wastewater (Figs. 3a, 3b). The removalefficiency of Lemna minor was found to be higher for oil and grease removal from $100 \%$ wastewater and $50 \%$ wastewater. Little significant differences exist between 
the removal efficiency of Lemna minor, Pistia stratiotes and Eichhornia crassipes in oil and grease removal if compare to oil and grease removal efficiency of Salvinia molesta and Azolla pinnata. The ability of the macrophytes to reduce TDS and TSS have been reported to be due to the particle sedimentation ability of the macrophytes which is due to there taining of the particle by the roots of macrophytes hence the reason why Pistia stratiotes and Eicchornia crassipes have higher TDS and TSS reduction efficiency than other macrophytes (da Silva et al., 2018; Osti et al., 2018). The reduction of oil and grease by the macrophytes is attributed to the enhancement of microbial growth caused by the presences of themacrophyteswhich in turncausesthedegradation of oil and greases (Amare et al., 2018b; Liu et al., 2010).

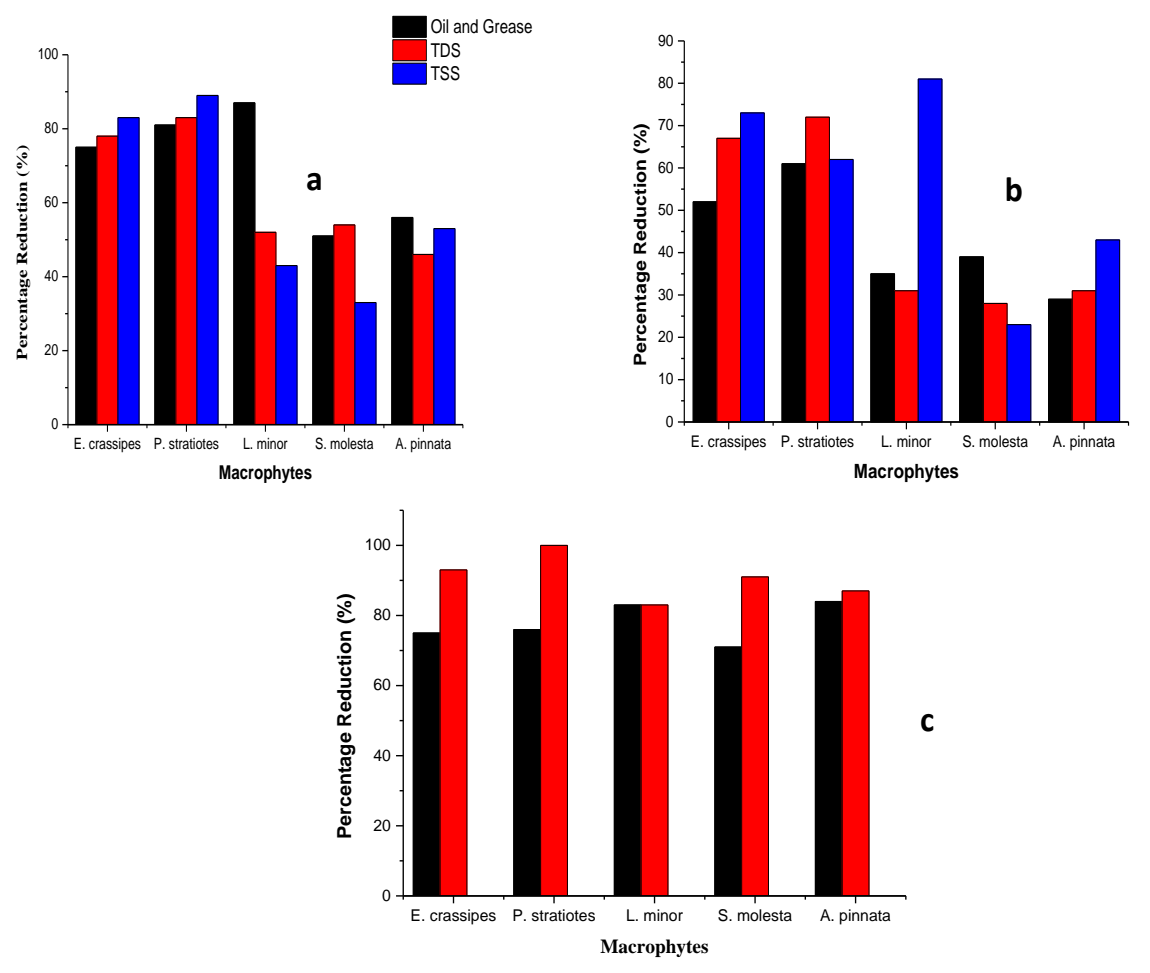

Figure 3. Efficiency of Macrophytes in Oil and grease, Total Dissolved Solids and Total Suspended Solid Reduction (a) 100\% Wastewater (b) 50\% Wastewater (C) Control

\section{The efficiency of Macrophytes in Chloride, Phenol, and Ammonical Nitrogen Reduction}

The result obtained shows a similar pattern for the removal of chloride, phenol and ammonical nitrogen present in $100 \%$ wastewater and $50 \%$ wastewater (Figs. 4a, $4 b$ ) by the macrophytes, with Eicchornia crassipes having the highest efficiency for chloride removal $(780 \mathrm{mg} / \mathrm{l}$ to $107 \mathrm{mg} / \mathrm{l})$ and Salvinia molesta having the highest efficiency for phenol and ammonical nitrogen removal $(13 \mathrm{mg} / \mathrm{l}$ to $3 \mathrm{mg} / \mathrm{l}$ and $87 \mathrm{mg} / \mathrm{l}$ to $14 \mathrm{mg} / \mathrm{l}$, respectively). The high phenol removal efficiency could be attributed to the fact that the presences of the macrophytes favor the growth of some microorganisms which help in the degradation of phenol (Mustapha et al., 2018; Suyamud et al., 2018). The high 
ammonical nitrogen and chloride \% reduction by the macrophytes is attributed to the fact that but nitrogen and chloride are needed for plant growth although chloride are needed in minute quantity, so there as on for the high chloride removal efficiency could be due to the fact that the concentration of chloride in the wastewater was minute (Han et al., 2018).
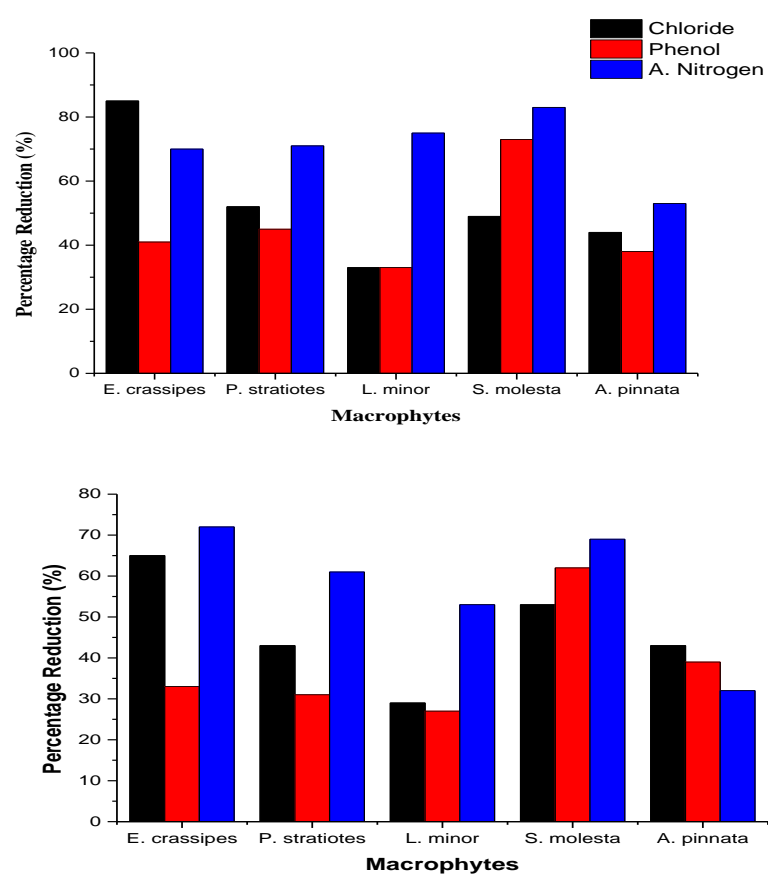

Figure 4. Efficiency of Macrophytes in Chloride, Phenol and Ammonical Nitrogen Reduction (a) $100 \%$ Wastewater (b) $50 \%$ Wastewater

\section{Heavy Metal Removal Efficiency, Bioconcentration and BiotranslocationFactor}

The result obtained shows high heavy metal removal efficiency by the entire test macrophytes (Fig. 5). This result obtained could be due to the fact that the heavy metal present in the wastewater was in low concentration with the highest been $10 \mathrm{ug} / \mathrm{l}$. Several researchers such as Malar et al. (2014) have show that most macrophytes have the ability to effectively utilized heavy metal to a concentration of within 10 mg/l-15 mg/l (Sharma et al., 2015; Teles Gomes et al., 2014; Török et al., 2015). The BTF and BTC factor obtained in Tables 2 and 3 respectively show that Eicchornia crassipes have the highest bioconcentration and biotranslocation factorfor $\mathrm{Cd}^{2+}$ and $\mathrm{Ni}^{3+}$ signifying that the plant can effectively absorb $\mathrm{Cd}^{2+}$ and $\mathrm{Ni}^{2+}$ from the wastewater and successfully transport the heavy metal totheshoot (stem and leaves) for utilization. Pistia stratiotes effectively absorbed and translocated $\mathrm{Cr}^{3+}$ and $\mathrm{Pb}^{2+}$ due to the high biotranslocation and bioconcentration factor recorded in Tables 2 and 3, respectively. This also shows that the plants were able to properly utilize the absorbed heavy metals. Lemna minor, Azolla pinnata, and Salvinia molesta were found to have accumulated the heavy metals, they still are not better accumulators if compared to Eicchornia crassipes and Pistia stratiotes (Amare et al., 2018b). 


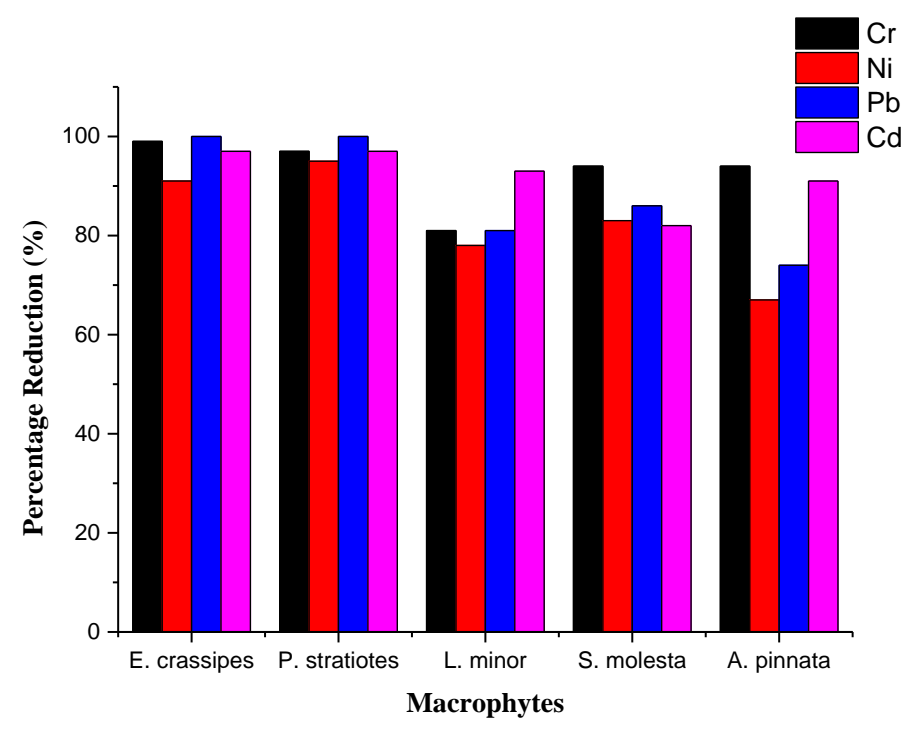

Figure 5. Efficiency of Macrophytes in heavy metal Reduction

Table 2. Biotranslocation Factor of Macrophytes

\begin{tabular}{c|c|c|c|c|c}
\hline SN & PLANT SAMPLE & $\mathbf{C D}^{\mathbf{2 +}}$ & $\mathbf{N I}^{\mathbf{2 +}}$ & $\mathbf{P B}^{\mathbf{2 +}}$ & $\mathbf{C R}^{\mathbf{3 +}}$ \\
\hline $\mathbf{1}$ & EICCHORNIA CRASSIPES & 2.3 & 1.7 & 1.4 & 1.6 \\
$\mathbf{2}$ & PISTIA STRATIOTES & 1.8 & 1.5 & 1.7 & 1.8 \\
$\mathbf{3}$ & LEMNA MINOR & 0.4 & 0.8 & 1.4 & 0.4 \\
$\mathbf{4}$ & SALVINIA MOLESTA & 1.2 & 1.1 & 0.9 & 1.5 \\
$\mathbf{5}$ & AZOLLA PINNATA & 0.7 & 1.6 & 1.6 & 0.9 \\
\hline
\end{tabular}

Table 3. Mean Bioconcentration Factor of Macrophytes

\begin{tabular}{c|c|c|c|c|c}
\hline SN & PlaNT SAMPLE & $\mathbf{C D}^{\mathbf{2 +}}$ & $\mathbf{N I}^{\mathbf{2 +}}$ & $\mathbf{P B}^{\mathbf{2 +}}$ & $\mathbf{C R}^{\mathbf{3 +}}$ \\
\hline $\mathbf{1}$ & EICCHORNIA CRASSIPES & 1.2 & 1.4 & 0.9 & 0.7 \\
$\mathbf{2}$ & PISTIA STRATIOTES & 1.1 & 1.3 & 1.6 & 1.9 \\
$\mathbf{3}$ & LEMNA MINOR & 0.7 & 0.8 & 0.5 & 0.6 \\
$\mathbf{4}$ & SALVINIA MOLESTA & 0.4 & 0.3 & 0.4 & 0.6 \\
$\mathbf{5}$ & AZOLLA PINNATA & 0.3 & 0.5 & 0.3 & 0.4 \\
\hline
\end{tabular}

\section{Conclusion}

Although, all the test plants show the ability of removal of pollutants from wastewater resulting from dying activities when compare to the control and 50\% dilution, Eicchornia crassipes, Lemna minor L., and Pistia stratiotes proof to be more efficient in the the remediation of wastewater resulting from dying and can be used in dyeing wastewater sedimentation and treatment before discharge into drainage system to prevent effects on aquatic flora and fauna.

Acknowledgements. The first author is thankful Nigeria Petroleum Development Fund (Nigeria) for providing the fund and enabling the environment to carry out the research. 


\section{REFERENCES}

[1] AFNOR. (2001): Maintenance terminology. - European standard, NF EN 13306.

[2] Akhtar, M. S., Oki, Y., Nakashima, Y., Nishigaki, M., Adachi, T., Kamigaki, T. (2016): Microcosm Investigation on Differential Potential of Free-Floating Azolla Macrophytes for Phytoremediation of P-controlled Water Eutrophication. - International Journal of Agriculture and Biology 18(1): 204-212.

[3] Amare, E., Kebede, F., Berihu, T., Mulat, W. (2018a): Field-based investigation on phytoremediation potentials of Lemna minor and Azolla filiculoides in tropical, semiarid regions: Case of Ethiopia. - International Journal of Phytoremediation 20(10): 965-972. doi: 10.1080/15226514.2017.1365333.

[4] Amare, E., Kebede, F., Mulat, W. (2018b): Wastewater treatment by Lemna minor and Azolla filiculoides in tropical semi-arid regions of Ethiopia. - Ecological Engineering 120: 464-473. doi: 10.1016/j.ecoleng.2018.07.005.

[5] Augustynowicz, J., Tokarz, K., Baran, A., Plachno, B. J. (2014): Phytoremediation of Water Polluted by Thallium, Cadmium, Zinc, and Lead with the Use of Macrophyte Callitriche cophocarpa. - Archives of Environmental Contamination and Toxicology 66(4): 572-581. doi: 10.1007/s00244-013-9995-0.

[6] Bokhari, S. H., Ahmad, I., Mahmood-Ul-Hassan, M., Mohammad, A. (2016): Phytoremediation potential of Lemna minor L. for heavy metals. - International Journal of Phytoremediation 18(1): 25-32. doi: 10.1080/15226514.2015.1058331.

[7] Braun, M., Zavanyi, G., Laczovics, A., Berenyi, E., Szabo, S. (2018): Can aquatic macrophytes be biofilters for gadolinium based contrasting agents? - Water Research 135: 104-111. doi: 10.1016/j.watres.2017.12.074.

[8] Bununu, Y. A., Ludin, A. N. M., Hosni, N. (2015): City profile: Kaduna. - Cities 49: 5365. doi: 10.1016/j.cities.2015.07.004.

[9] Carvalho, C. F. M. d., Viana, D. G., Pires, F. R., Egreja Filho, F. B., Bonomo, R., Martins, L. F., Rocha Junior, P. R. d. (2018): Phytoremediation of barium-affected flooded soils using single and intercropping cultivation of aquatic macrophytes. Chemosphere 214: 10-16. doi: 10.1016/j.chemosphere.2018.09.096.

[10] Costa, M. B., Tavares, F. V., Martinez, C. B., Colares, I. G., Gaspar Martins, C. d. M. (2018): Accumulation and effects of copper on aquatic macrophytes Potamogeton pectinatus L.: Potential application to environmental monitoring and phytoremediation. Ecotoxicology and Environmental Safety 155: 117-124. doi: 10.1016/j.ecoenv.2018.01.062.

[11] da Silva, A. A., de Oliveira, J. A., de Campos, F. V., Ribeiro, C., Farnese, F. d. S., Costa, A. C. (2018): Phytoremediation potential of Salvinia molesta for arsenite contaminated water: role of antioxidant enzymes. - Theoretical and Experimental Plant Physiology 30(4): 275-286. doi: 10.1007/s40626-018-0121-6.

[12] Demarco, C. F., Afonso, T. F., Pieniz, S., Quadro, M. S., Camargo, F. A. O., Andreazza, R. (2018): In situ phytoremediation characterization of heavy metals promoted by Hydrocotyle ranunculoides at Santa Barbara stream, an anthropogenic polluted site in southern of Brazil. - Environmental Science and Pollution Research 25(28): 2831228321. doi: 10.1007/s11356-018-2836-y.

[13] Di Luca, G. A., Hadad, H. R., Mufarrege, M. M., Maine, M. A., Sanchez, G. C. (2014): Improvement of $\mathrm{Cr}$ phytoremediation by Pistia stratiotes in presence of nutrients. International Journal of Phytoremediation 16(2): 167-178. doi: 10.1080/15226514.2012.759535.

[14] Fernandes, K. D., Canote, S. J. B., Ribeiro, E. M., Thiago Filho, G. L., Fonseca, A. L. (2018): Can we use Cd-contaminated macrophytes for biogas production? Environmental science and pollution research international. doi: 10.1007/s11356-0182318-2. 
[15] Fernandez San Juan, M. R., Albornoz, C. B., Larsen, K., Najle, R. (2018): Bioaccumulation of heavy metals in Limnobium laevigatum and Ludwigia peploides: their phytoremediation potential in water contaminated with heavy metals. Environmental Earth Sciences 77(11). doi: 10.1007/s12665-018-7566-4.

[16] Galal, T. M., Gharib, F. A., Ghazi, S. M., Mansour, K. H. (2017): Phytostabilization of heavy metals by the emergent macrophyte Vossia cuspidata (Roxb.) Griff.: A phytoremediation approach. - International Journal of Phytoremediation 19(11): 992-999. doi: 10.1080/15226514.2017.1303816.

[17] Haddad, M., Abid, S., Hamdi, M., Bouallagui, H. (2018): Reduction of adsorbed dyes content in the discharged sludge coming from an industrial textile wastewater treatment plant using aerobic activated sludge process. - Journal of Environmental Management 223: 936-946. doi: 10.1016/j.jenvman.2018.07.009.

[18] Han, L., Fu, T., Liu, J., Yu, S., Gao, H., Eneji, A. E., Liang, H. (2018): Accumulation and distribution of calcium and magnesium in oat and correlation analysis with the uptake of sodium, potassium, and chloride elements. - Communications in Soil Science and Plant Analysis 49(22): 2765-2781. doi: 10.1080/00103624.2018.1538375.

[19] Irawati, W., Parhusip, A. J. N., Sopiah, N., Tnunay, J. A. (2017): The Role of Heavy Metals-Resistant Bacteria Acinetobacter sp in Copper Phytoremediation using Eichhornia crasippes (Mart.) Solms. - In: Setyobudi, R. H., Purwanto, M. G. M., Burlakovs, J., Mel, M., Adinurani, P. G., VincevicaGaile, Y. (eds.) International Conference on Natural Resources and Life Science, pp. 208-220.

[20] Jiang, B., Xing, Y., Zhang, B., Cai, R., Zhang, D., Sun, G. (2018): Effective phytoremediation of low-level heavy metals by native macrophytes in a vanadium mining area, China. - Environmental science and pollution research international. doi: 10.1007/s11356-018-3069-9.

[21] Kaminski, A., Bober, B., Chrapusta, E., Bialczyk, J. (2014): Phytoremediation of anatoxin-a by aquatic macrophyte Lemna trisulca L. - Chemosphere 112: 305-310. doi: 10.1016/j.chemosphere.2014.04.064.

[22] Klink, A. (2017): A comparison of trace metal bioaccumulation and distribution in Typha latifolia and Phragmites australis: implication for phytoremediation. - Environmental Science and Pollution Research 24(4): 3843-3852. doi: 10.1007/s11356-016-8135-6.

[23] Liu, W., Luo, Y., Teng, Y., Li, Z. G. (2010): Phytoremediation of Oilfield Sludge After Prepared Bed Bioremediation Treatment. - International Journal of Phytoremediation 12(3): 268-278. doi: 10.1080/15226510903563876.

[24] Lyu, W., Yu, M., Feng, J., Yan, W. (2018): Highly crystalline polyaniline nanofibers coating with low-cost biomass for easy separation and high efficient removal of anionic dye ARG from aqueous solution. - Applied Surface Science 458: 413-424. doi: 10.1016/j.apsusc.2018.07.074.

[25] Malar, S., Shivendra Vikram, S., Jc Favas, P., Perumal, V. (2014): Lead heavy metal toxicity induced changes on growth and antioxidative enzymes level in water hyacinths [Eichhornia crassipes (Mart.)]. - Botanical Studies 55(1): 54. doi: 10.1186/s40529-0140054-6.

[26] Maleva, M., Chukina, N., Borisova, G. (2016): Aquatic macrophytes as effective heavy metal accumulators from industrial wastewaters: Significance for phytoremediation. New Biotechnology 33: S144-S145. doi: 10.1016/j.nbt.2016.06.1221.

[27] Mustapha, H. I., van Bruggen, H. J. J. A., Lens, P. N. L. (2018): Vertical subsurface flow constructed wetlands for the removal of petroleum contaminants from secondary refinery effluent at the Kaduna refining plant (Kaduna, Nigeria). - Environmental Science and Pollution Research 25(30): 30451-30462. doi: 10.1007/s11356-018-2996-9.

[28] Neagu, D., Arduini, F., Quintana, J. C., Di Cori, P., Forni, C., Moscone, D. (2014): Disposable Electrochemical Sensor to Evaluate the Phytoremediation of the Aquatic Plant Lemna minor L. toward $\mathrm{Pb} 2+$ and/or Cd2+. - Environmental science \& technology 48(13): 7477-7485. doi: 10.1021/es500675x. 
[29] Ng, Y. S., Chan, D. J. C. (2017): Wastewater phytoremediation by Salvinia molesta. Journal of Water Process Engineering 15: 107-115.

[30] Ogwueleka, T. C. (2014): Assessment of the water quality and identification of pollution sources of Kaduna River in Niger State (Nigeria) using exploratory data analysis. - Water and Environment Journal 28(1): 31-37. doi: 10.1111/wej.12004.

[31] Ogwueleka, T. C. (2015): Use of multivariate statistical techniques for the evaluation of temporal and spatial variations in water quality of the Kaduna River, Nigeria. Environmental Monitoring and Assessment 187(3). doi: 10.1007/s10661-015-4354-4.

[32] Osti, J. A. S., Henares, M. N. P., Camargo, A. F. M. (2018): The efficiency of freefloating and emergent aquatic macrophytes in constructed wetlands for the treatment of a fishpond effluent. - Aquaculture Research 49(10): 3468-3476. doi: 10.1111/are.13813.

[33] Pandian, L., Rajasekaran, R., Govindan, P. (2018): Synthesis, characterization and application of $\mathrm{Cu}$ doped $\mathrm{ZnO}$ nanocatalyst for photocatalytic ozonation of textile dye and study of its reusability. - Materials Research Express 5(11). doi: 10.1088/20531591/aadcdf.

[34] Qin, H., Zhang, Z., Liu, M., Liu, H., Wang, Y., Wen, X., Yan, S. (2016): Site test of phytoremediation of an open pond contaminated with domestic sewage using water hyacinth and water lettuce. - Ecological Engineering 95: 753-762. doi: 10.1016/j.ecoleng.2016.07.022.

[35] Qu, M., Li, H., Li, N., Liu, G., Zhao, J., Hua, Y., Zhu, D. (2017): Distribution of atrazine and its phytoremediation by submerged macrophytes in lake sediments. - Chemosphere 168: 1515-1522. doi: 10.1016/j.chemosphere.2016.11.164.

[36] Riaz, G., Tabinda, A. B., Iqbal, S., Yasar, A., Abbas, M., Khan, A. M., Baqar, M. (2017): Phytoremediation of organochlorine and pyrethroid pesticides by aquatic macrophytes and algae in freshwater systems. - International Journal of Phytoremediation 19(10): 894898. doi: 10.1080/15226514.2017.1303808.

[37] Saraswat, S., Rai, J. P. N. (2018): Aquatic macrophytes mediated remediation of toxic metals from moderately contaminated industrial effluent. - International Journal of Phytoremediation 20(9): 876-884. doi: 10.1080/15226514.2018.1438359.

[38] Sharma, S., Singh, B., Manchanda, V. K. (2015): Phytoremediation: role of terrestrial plants and aquatic macrophytes in the remediation of radionuclides and heavy metal contaminated soil and water. - Environmental Science and Pollution Research 22(2): 946-962. doi: 10.1007/s11356-014-3635-8.

[39] Singh, M. M., Rai, P. K. (2016): A microcosm investigation of fe (iron) removal using macrophytes of ramsar lake: A phytoremediation approach. - International Journal of Phytoremediation 18(12): 1231-1236. doi: 10.1080/15226514.2016.1193471.

[40] Suyamud, B., Thiravetyan, P., Panyapinyopol, B., Inthorn, D. (2018): Dracaena sanderiana endophytic bacteria interactions: Effect of endophyte inoculation on bisphenol A removal. - Ecotoxicology and Environmental Safety 157: 318-326. doi: 10.1016/j.ecoenv.2018.03.066.

[41] Teles Gomes, M. V., de Souza, R. R., Teles, V. S., Mendes, E. A. (2014): Phytoremediation of water contaminated with mercury using Typha domingensis in constructed wetland. - Chemosphere 103: 228-233. doi: 10.1016/j.chemosphere.2013.11.071.

[42] Ting, W. H. T., Tan, I. A. W., Salleh, S. F., Wahab, N. A. (2018): Application of water hyacinth (Eichhornia crassipes) for phytoremediation of ammoniacal nitrogen: A review. - Journal of Water Process Engineering 22: 239-249. doi: 10.1016/j.jwpe.2018.02.011.

[43] Török, A., Gulyás, Z., Szalai, G., Kocsy, G., Majdik, C. (2015): Phytoremediation capacity of aquatic plants is associated with the degree of phytochelatin polymerization. Journal of Hazardous Materials 299: 371-378. doi: 10.1016/j.jhazmat.2015.06.042.

[44] Ugya, A. Y. (2015): The Efficiency of Lemna minor L. in the Phytoremediation of Romi Stream: A case Study of Kaduna Refinery and Petrochemical Company Polluted Stream. - Journal of Applied Biology and Biotechnology 3: 11-14. 
[45] Vanhoudt, N., Van Ginneken, P., Nauts, R., Van Hees, M. (2018): Potential of four aquatic plant species to remove Co-60 from contaminated water under changing experimental conditions. - Environmental Science and Pollution Research 25(27): 2718727195. doi: 10.1007/s11356-018-2759-7.

[46] Victor, K. K., Seka, Y., Norbert, K. K., Sanogo, T. A., Celestin, A. B. (2016): Phytoremediation of wastewater toxicity using water hyacinth (Eichhornia crassipes) and water lettuce (Pistia stratiotes). - International Journal of Phytoremediation 18(10): 949955. doi: 10.1080/15226514.2016.1183567.

[47] Zhao, L., Zhao, W., Guo, W., Li, H., Long, M. (2016): Phytoremediation Mechanism of Sediment Contaminated with Pentachlorophenol by Aquatic Macrophytes. - In: Zhou, P., Chen, S., Chen, K. (eds.) Proceedings of the 2016 2nd International Conference on Architectural, Civil and Hydraulics Engineering 99: 78-81.

[48] Zhao, L., Guo, W., Li, Q., Li, H., Zhao, W., Cao, X. (2017): Capabilities of Seven Species of Aquatic Macrophytes for Phytoremediation of Pentachlorophenol Contaminated Sediment. - International Conference on Environmental Engineering and Sustainable Development 51.

[49] Zhao, Z., Qin, Z., Xia, L., Zhang, D., Hussain, J. (2018): Dissipation characteristics of pyrene and ecological contribution of submerged macrophytes and their biofilms-leaves in constructed wetland. - Bioresource Technology 267: 158-166. doi: 10.1016/j.biortech.2018.06.060. 